\title{
EXPERIMENTAL INVESTIGATION ON FOAM CONCRETE WITH PARTIAL REPLACEMENT OF FINE AGGREATE BY FLY ASH AND CEMENT BY ALCCOFINE
}

\author{
Dr.G.V.V. SATYANARAYANA ${ }^{1}$ and G. PRAVEEN KUMAR ${ }^{2}$ \\ ${ }^{1}$ Professor, Department of Civil Engineering, GRIET, Hyderabad-500090 \\ ${ }^{2}$ P.G.Scholar, Dept. of Civil Engineering, GRIET, Hyderabad-500090
}

\begin{abstract}
As we know that Foam concrete has been successfully used and it has gained popularity due to its lower density than normal concrete. Globally the construction activities are rapid and using huge amount of fine aggregate and cement. Due to continuous usage of large amount of sand and cement we are creating natural imbalance by CONTINUOUS mining of sand, lime etc., from natural resources, which causes many natural hazards and become threat to humans. As a responsible citizen of world everyone think to stop the usage of sand and cement in huge quantity for infrastructural activities. Fly ash is one alternative solution as a partial replacement of sand and cement with Alccofine. In this investigation we are replacing fine aggregate with fly ash and cement with Alccofine by usage of Using additive materials in foam concrete which provides not only workability, strength but also reduce overall cost. As reducing the quantity of sand and cement in foam concrete we conserve Green House effect and also other raw materials used for cement. Foam concrete produced with uniform distribution of air bubbles thoughout the mass of concrete. The density of foam concrete is a function of the volume of foam added to the slurry and the strength decreases as decrease in densities. This experimental investigation was designed for density of $800 \mathrm{~kg} / \mathrm{m}^{3}$. This study was compiled in determination of workability, plastic density, water absorption and compressive strength of foam concrete. The test specimens has been casted and tested at the age of 7,14 and 28 days.
\end{abstract}

\section{INTRODUCTION}

All over the world different types concretes are using in construction activities like nominal concrete, light weight concrete etc. Each type concrete having its own properties and usage. Usually traditional concrete has a density varies from 2300 to $2400 \mathrm{~kg} / \mathrm{m} 3$, The foam or light weight concretes are classified into several types founded on their densities like low-density foam concrete $300-600 \mathrm{~kg} / \mathrm{m} 3$ which is normally used for thermal lining purpose and whereas medium-density foam concrete $800-1200 \mathrm{~kg} / \mathrm{m} 3$ which is generally used foe non-structural elements and high-density foam concrete $1200-1800 \mathrm{~kg} / \mathrm{m} 3$ used as structural elements like lintels, small beam sections etc., while light weight concrete has a density ranging from $300 \mathrm{~kg} / \mathrm{m}^{3}$ to $1800 \mathrm{~kg} / \mathrm{m}^{3}$. The cellular or aerated concretes become popular due to light in weight and durability also it can be handled easily. The role of foaming agent is also important factor to produce various types of foam concretes. In general two kinds of foam agents these are natural and synthetic foaming agents in production of foam concretes. Synthetic foaming agents are using to develop medium and high dense foam concretes. Dr.A.S.Kanaga Lakshmi et al. [1, 6] concluded that the foam concrete with quarry dust not only reduces cost but also eliminates additional compaction. Globally light weight concrete is using rapidly for modern constructions, because it can be produced with different densities and without coarse aggregate. Foam concrete is a new type of light weight building material which possesses incredible resistance against fire, sound and thermal. Foam concrete is preparing with foam and other cementious materials such as fly ash, GGBS etc. Foam concrete having low modulus of elasticity and high fluidity which improves workability and easy molding even foam works are thin or complex. Some of the common applications of foam concrete are roof tops, walls, cushion, floor warming and back filling engineering works. Ravi Shankar S et al.. [2, 7] stated that higher density will always not having high strength but it depends on water - cement ratio. Also foam concrete is more sensitive to water when compared with normal concrete. The density of foam concretes are depends on the quantity of foam concrete also. The strength of foam concrete decreases as water - cement ratio increases, so always maintain ideal water - cement ratio that is in between 0.4 to 0.8 with binder material. K Muthusamy et al. [3] concluded that compressive strength of foam concrete reaches its optimum at 30\% replacement of sand with quarry dust in preparation of foam concrete, by this we can avoid cost in disposal of waste materials and also protect the environment. Mr.S. Yuvaraj et al. [4] produced eco-friendly concrete with partial replacement of sand by M-sand, due to this the compressive strength increased up to $60 \%$ and decreases overall cost of concrete. Aswathy.M [5] reported that the continuous process of curing gives good thermal 
insulation and other advantages such as low labor, transport and handling cost.

\section{MATERIALS}

The materials used in the present investigation were explained in details shown in following tables:

\subsection{CEMENT}

In this investigation ordinary Portland cement of grade 53 conforming to IS 12269: (1987) and its properties are mentioned in Table 1

Table 1. PROPERTIES OF CEMENT

\begin{tabular}{|c|c|c|c|}
\hline $\begin{array}{c}\text { S.N } \\
\text { O }\end{array}$ & PROPERTY & $\begin{array}{c}\text { EXPERIMENTA } \\
\text { L RESULTS }\end{array}$ & $\begin{array}{c}\text { LIMITIN } \\
\text { G } \\
\text { VALUES } \\
\text { AS PER } \\
\text { CODE (IS } \\
\mathbf{1 2 2 9 : 1 9 8 7 )}\end{array}$ \\
\hline 1 & $\begin{array}{c}\text { Fineness (air- } \\
\text { permeability) }\end{array}$ & $2465 \mathrm{~cm}^{2} / \mathrm{g}$ & $\begin{array}{c}< \\
225 \mathrm{~m}^{2} / \mathrm{kg}\end{array}$ \\
\hline 2 & $\begin{array}{c}\text { Specific } \\
\text { gravity }\end{array}$ & 3.15 & $3.10-3.25$ \\
\hline 3 & $\begin{array}{c}\text { Standard } \\
\text { consistency }\end{array}$ & $33 \%$ & $26 \%-35 \%$ \\
\hline 4 & $\begin{array}{c}\text { Initial setting } \\
\text { time ( } \\
\text { minutes) }\end{array}$ & 48 minutes & $\begin{array}{c}<30 \\
\text { minutes }\end{array}$ \\
\hline 5 & $\begin{array}{c}\text { Final setting } \\
\text { time in } \\
\text { minutes }\end{array}$ & 270 minutes & $\begin{array}{c}\text { Not less } \\
\text { than } 600 \\
\text { minutes }\end{array}$ \\
\hline 6 & $\begin{array}{c}\text { Compressive } \\
\text { strength at } 28 \\
\text { days(N/mm }\end{array}$ & & $\begin{array}{c}\text { Not less } \\
\text { than } 53 \\
\text { N/mm }\end{array}$ \\
\hline
\end{tabular}

\subsection{FILLER MATERIAL}

River sand of specific gravity 2.6 and which is passing through $0.6 \mathrm{~mm}$ sieve is used for this experimental investigation. Properties of sand are shown in the Table 2

Table 2. PROPERTIES OF SAND

\begin{tabular}{|c|c|c|c|}
\hline S.NO & PROPERTIES & VALUES & $\begin{array}{c}\text { STANDARD } \\
\text { VALUES }\end{array}$ \\
\hline 1 & $\begin{array}{c}\text { Specific } \\
\text { gravity }\end{array}$ & 2.6 & $2.6-2.85$ \\
\hline 2 & Fineness & 2.67 & $2-4$ \\
\hline
\end{tabular}

\subsection{FLY ASH:}

In this experimental investigation class-F fly ash used, which is collected from near by RMC plant. Properties of Fly ash is mentioned in Table 3

Table 3, PROPERTIES OF FLY ASH

\begin{tabular}{|c|c|c|}
\hline S.NO & PROPERTIES & VALUES \\
\hline 1 & Specific gravity & 2.07 \\
\hline 2 & Fineness $\left(\mathrm{m}^{3} / \mathrm{kg}\right)$ & 290 \\
\hline 3 & Bulk density $\left(\mathrm{kg} / \mathrm{m}^{2}\right)$ & $1100-1200$ \\
\hline
\end{tabular}

\begin{tabular}{l|l|l}
4 & Color (visual observation) & Light grey
\end{tabular}

\subsection{ALCCOFINE}

It is a new type of micro fine concrete material, it helps to improve workability and strength. It can be directly added to the cement. It also helps to give smooth surface finish due to its ultra-fineness. Its properties are mentioned in Table 4

Table 4. PROPERTIES OF ALCCOFINE

\begin{tabular}{|c|c|c|}
\hline S.NO & PHYSICAL & VALUES \\
& PROPERTIES & \\
\hline 1 & Particle size & \\
& distribution (in mm) & \\
& d10 & 1.8 \\
& d50 & 4.4 \\
& d90 & 8.9 \\
\hline 2 & Bulk density & 680 \\
\hline 3 & Specific gravity & 2.70 \\
\hline
\end{tabular}

\subsection{FOAMING AGENT}

In this investigation synthetic foaming agent was used to prepare foam. The foaming agent is collected from the local CLC brick manufacturer. This synthetic foaming agent helps to reduce surface tension of liquid the agent is mixed with water in the ratio of 1:30. To generate foam we had used foam generator, which is connected to air compressor. Then the air compressor is started and we have to wait until the air pressure in the compressor reaches to $2 \mathrm{lbs}$ and then we have to open the valve of air compressor, which allows air to enter in to foam generator. In foam generator we have maintain constant pressure of $2 \mathrm{lbs}$, then after 5 minutes we can generate thick foam.

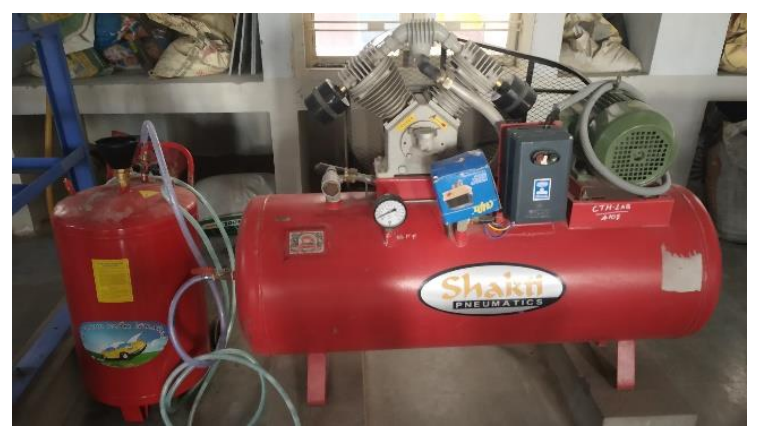

Fig. 1. FOAM GENERATOR CONNECTED TO AIR COMPRESSOR

\section{METHODOLOGY}

In this experimental investigation foam concrete mix proportions was fixed with suitable mix design procedure based on the previous literature. Once mix design got ready, trail mixes have made to check whether the target density has been achieved or not. If the target density has not achieved some modification has been made in water cement ratio and finalized the mix proportions. Then for the required densities cubes has been casted with and without replacements. Weights of molds is noted down before and after casting. By this way verified the target density achieved or not. Then the cubes have been placed in curing tank after completion of curing, Foam concrete is tested for target density. If the cubes reached target density compressive strength will carried out. 


\section{MIX DESIGN:}

At present there is no appropriate mix design for foam concrete. Target density is a key factor to design and fix up the proportions of foam concrete, but in design of conventional concrete target strength is a key factor to achieve mix design. Based on the past literature survey density is primary factor to conclude mix proportions in foam concrete. In general the compressive strength decreases with the decrease in densities of concrete. But in foam concrete weight-based $\operatorname{mix}$ proportions are meaningless for calculating required amount of materials because of free pores formed the hardened density may vary up to $10 \%$. So, foam concrete is usually proportioned on volume basis.

In this investigation cement content is calculated by assuming water/cement and sand/cement ratios. The main formula used to calculate amount of materials required is mentioned below:

Target density $=[$ Cement content $(C)+$ Water content $(\mathrm{W})$

$$
+ \text { Fine aggregate }(\mathrm{F})]
$$

To calculate volume of Foam below formula is used $\mathrm{V}\left(\mathrm{m}^{3}\right.$ of concrete $)=[\mathrm{V}($ Foam $)+\mathrm{V}($ Cement $)+\mathrm{V}($ Sand $)+$ $\mathrm{V}$ (water)]

$1 \mathrm{~m}^{3}=\mathrm{V}($ foam $)+\frac{\mathrm{Wc}}{(\mathrm{Sc} \times \mathrm{Dw})}+\frac{\mathrm{Ww}}{(\mathrm{Sw} \times \mathrm{Dw})}+\frac{\mathrm{Ws}}{(\mathrm{Ss} \times \mathrm{Dw})}$

Where,

Wc- Weight of cement

Ws- Weight of sand

Ww-Weight of water

Dw- Density of water

Sc- Specific gravity of cement

Ss- Specific gravity of sand

Sw- Specific gravity of water

By substitution of known values in the above equation, the volume of foam arrived. Replacements in the percentages of $30 \%, 20 \%, 10 \%$ of Alccofine and Fly ash is done. In this investigation take volume of foam value is constant as 0.603 $\mathrm{m}^{3}$ in every trail mix.

Table 5. MIX DESIGN - 1 (WITHOUT ANY REPLACEMENT)

\begin{tabular}{|c|c|c|c|c|c|}
\hline $\begin{array}{c}\text { DENSIT } \\
\text { Y } \\
\left(\mathrm{kg} / \mathrm{m}^{3}\right)\end{array}$ & $\begin{array}{c}\text { CEMENT } \\
\text { CONTEN } \\
T \\
(\mathrm{~kg} / \mathrm{m} 3)\end{array}$ & $\begin{array}{c}\text { SAND } \\
\text { CONTEN } \\
\text { T } \\
(\mathrm{kg} / \mathrm{m} 3)\end{array}$ & $\begin{array}{c}\text { FLY } \\
\text { ASH } \\
(\mathrm{kg} / \mathrm{m3} \\
)\end{array}$ & $\begin{array}{l}\text { ALCCO } \\
\text { FINE } \\
(\mathrm{kg} / \mathrm{m3})\end{array}$ & $\begin{array}{l}\text { WA } \\
\text { TER } \\
\text { (kg/ } \\
\text { m3) }\end{array}$ \\
\hline 800 & 210.52 & 0 & 421.04 & $\mathbf{0}$ & 0.603 \\
\hline
\end{tabular}

Table 6. MIX DESIGN - 2

(WITH REPLACEMENT RATIO OF 90\% - 10\%)

\begin{tabular}{|c|c|c|c|c|c|}
\hline $\begin{array}{c}\text { DENSI } \\
\text { TY } \\
(\mathrm{kg} / \mathrm{m} 3)\end{array}$ & $\begin{array}{c}\text { CEMEN } \\
\text { T } \\
\text { CONTE } \\
\text { NT } \\
(\mathrm{kg} / \mathrm{m} 3)\end{array}$ & $\begin{array}{c}\text { SAND } \\
\text { CONTE } \\
\text { NT } \\
(\mathrm{kg} / \mathrm{m} 3)\end{array}$ & $\begin{array}{c}\text { FLY } \\
\text { ASH } \\
(\mathrm{kg} / \mathrm{m}\end{array}$ & $\begin{array}{c}\text { ALCCOF } \\
\text { INE } \\
(\mathrm{kg} / \mathrm{m} 3)\end{array}$ & $\begin{array}{c}\text { WATE } \\
\text { R } \\
(\mathrm{kg} / \mathrm{m} 3 \\
)\end{array}$ \\
\hline 800 & 189.46 & 42.104 & 378.9 & 21.05 & 168.41 \\
& & & 3 & & \\
\hline
\end{tabular}

Table 7. MIX DESIGN - 3

(WITH REPLACEMENT RATIO OF 80\% - 20\%)

\begin{tabular}{|c|c|c|c|c|c|}
\hline $\begin{array}{c}\text { DENSI } \\
\text { TY } \\
(\mathrm{kg} / \mathrm{m} 3)\end{array}$ & $\begin{array}{c}\text { CEMEN } \\
\text { T } \\
\text { CONTE } \\
\text { NT } \\
(\mathrm{kg} / \mathrm{m} 3)\end{array}$ & $\begin{array}{c}\text { SAND } \\
\text { CONTE } \\
\text { NT } \\
(\mathrm{kg} / \mathrm{m} 3)\end{array}$ & $\begin{array}{c}\text { FLY } \\
\text { ASH } \\
(\mathrm{kg} / \mathrm{m} \\
\mathbf{3})\end{array}$ & $\begin{array}{c}\text { ALCCOFI } \\
\text { NE } \\
(\mathrm{kg} / \mathrm{m} 3)\end{array}$ & $\begin{array}{c}\text { WAT } \\
\text { ER } \\
(\mathrm{kg} / \mathrm{m} 3\end{array}$ \\
& & & & \\
\hline 800 & 168.41 & 84.20 & 336.8 & 42.10 & 168.41 \\
& & & 3 & & \\
\hline
\end{tabular}

TABLE 8 MIX DESIGN - 4 (WITH REPLACEMENT RATIO

\begin{tabular}{|c|c|c|c|c|c|}
\hline $\begin{array}{c}\text { DENSI } \\
\text { TY } \\
(\mathrm{kg} / \mathrm{m} 3)\end{array}$ & $\begin{array}{c}\text { CEMEN } \\
\text { T } \\
\text { CONTE } \\
\text { NT } \\
(\mathrm{kg} / \mathrm{m} 3)\end{array}$ & $\begin{array}{c}\text { SAND } \\
\text { CONTE } \\
\text { NT } \\
(\mathrm{kg} / \mathrm{m} 3)\end{array}$ & $\begin{array}{c}\text { FLY } \\
\text { ASH } \\
(\mathrm{kg} / \mathrm{m} \\
\text { 3) }\end{array}$ & $\begin{array}{c}\text { ALCCOFI } \\
\text { NE } \\
(\mathrm{kg} / \mathrm{m} 3)\end{array}$ & $\begin{array}{c}\text { WAT } \\
\text { ER } \\
(\mathrm{kg} / \mathrm{m} 3 \\
)\end{array}$ \\
\hline 800 & 147.36 & 126.31 & $\begin{array}{c}294.7 \\
2\end{array}$ & 63.15 & 168.41 \\
\hline
\end{tabular}

\section{EXPERIMENTAL INVESTIGATION}

In this context we mainly discuss about the performance of foam concrete with partial replacement of cement with Alccofine and sand with fly ash. Then tests were conducted according to the IS standards such as workability, densities and compressive strength. The results presented below are obtained after the tests were conducted for all the mixes mentioned above.

\subsection{WORKABILITY TEST:}

In this investigation Flow table is used to estimate the workability of foam concrete. Apparatus of flow table is made up with steel and its dimensions are $750 \mathrm{~mm} \times 750 \mathrm{~mm}$ $\mathrm{X} 1.5 \mathrm{~mm}$ (thick). The flow table having concentric circles on top surface which is useful to measure workability, along with there a metal cone having lower diameter $20 \mathrm{~cm}$ and upper diameter $13 \mathrm{~cm}$ and height of cone about $20 \mathrm{~cm}$. It consists a handles to lift on the flow table for measuring flow of concrete.

\subsection{PROCEDURE:}

First weigh down all materials as per design proportions. After batching of the required quantities of materials are taken into concrete mixer and mixed required quantity of water and foam to achieve the target density. Then tested the foam concrete for workability using flow table. Then mixed foam concrete transfer into the cone after trimming the top surface gently lifted the cone and measure the flow ability of mix along the concentric circle take at least in two directions and note down its average value. Then the flow values are noted down and we should calculate workability.

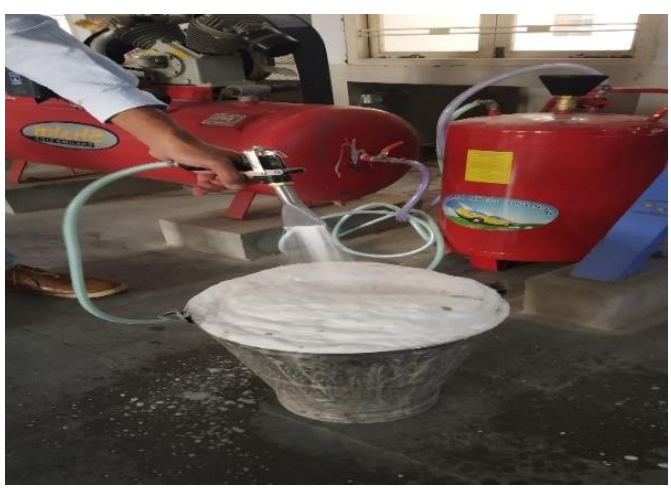

Fig. 2. FOAM GENERATED FORM USING FOAM GENERATOR 


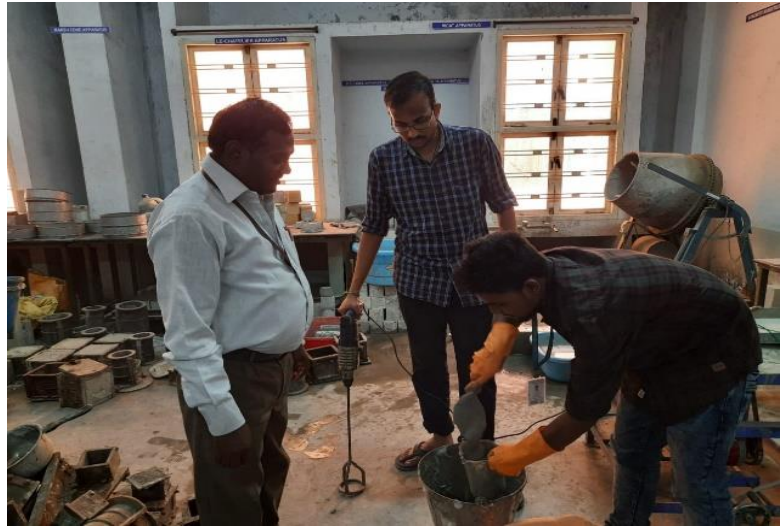

Fig. 3. MIXING OF FOAM CONCRETE

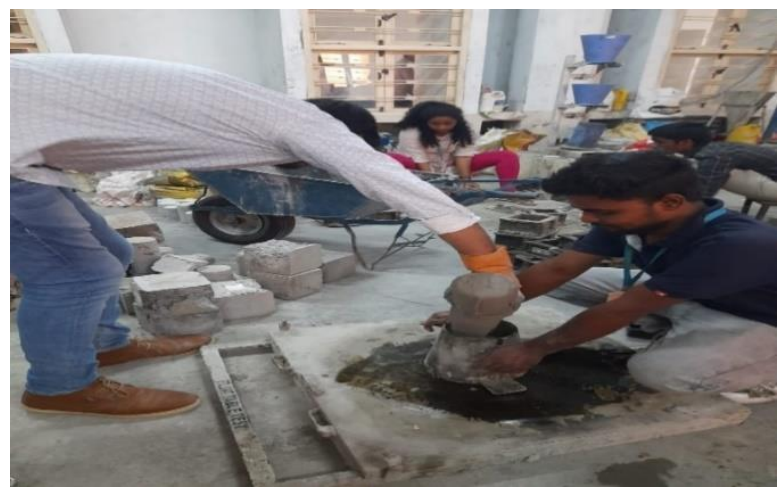

Fig. 4. PERFORMING FLOW TABLE TESTS

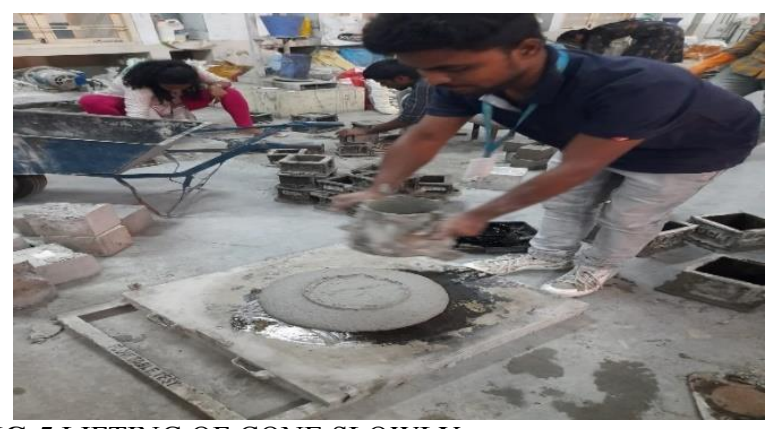

FIG-5 LIFTING OF CONE SLOWLY

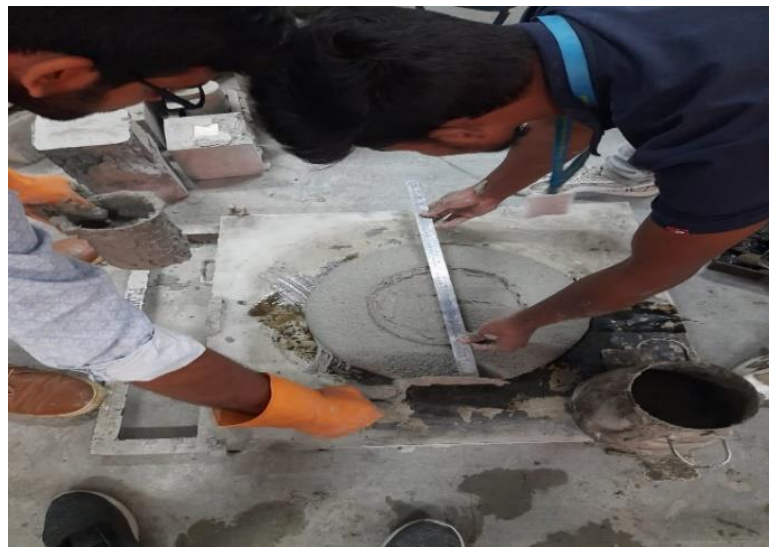

Fig. 6. MEASURING THE FLOW OF THE CONCRETE

TABLE 9 WORKABILITY VALUES

\begin{tabular}{|c|c|c|}
\hline DENSITY & TRIAL MIX & $\begin{array}{c}\text { WORKABILITY } \\
(\mathbf{m m})\end{array}$ \\
\hline 800 & MIX -1 & 447 \\
\hline 800 & MIX -2 & 437 \\
\hline 800 & MIX -3 & 435 \\
\hline 800 & MIX -4 & 432 \\
\hline
\end{tabular}

\subsection{PLASTIC DENSITY}

In this investigation plastic density of cubes is calculated. To determine plastic density, we need to subtract weight of mould filled with material (W2) and weight of an empty mould (W1).

\begin{tabular}{|c|c|c|}
\multicolumn{1}{|c|}{ TABLE 10 PLASTIC DENSITY VALUES } \\
\begin{tabular}{|c|c|c|}
\hline DENSITY & TRIAL MIX & $\begin{array}{c}\text { PLASTIC } \\
\text { DENSITY } \\
\left(\mathbf{k g} / \mathbf{m}^{\mathbf{3}}\right)\end{array}$ \\
\hline 800 & MIX-1 & 2.93 \\
\hline 800 & MIX-2 & 2.8 \\
\hline 800 & MIX-3 & 2.87 \\
\hline 800 & MIX-4 & 2.81 \\
\hline
\end{tabular}
\end{tabular}

TABLE 11 DRY DENSITY

\begin{tabular}{|c|c|c|}
\hline DENSITY & $\begin{array}{c}\text { TRIAL } \\
\text { MIX }\end{array}$ & DRY DENSITY \\
\hline 800 & MIX-1 & 2.75 \\
\hline 800 & MIX-2 & 2.72 \\
\hline 800 & MIX-3 & 2.78 \\
\hline 800 & MIX-4 & 2.76 \\
\hline
\end{tabular}

TABLE 12 COMPRESSIVE STRENGTH

\begin{tabular}{|c|c|c|c|c|c|}
\hline \multirow[t]{2}{*}{$\begin{array}{c}\text { S.N } \\
\text { O }\end{array}$} & \multirow{2}{*}{$\begin{array}{c}\text { DENSITY } \\
\text { OF FOAM } \\
\text { CONCRET } \\
\text { E } \\
\left(\mathrm{kg} / \mathrm{m}^{3}\right)\end{array}$} & \multirow[t]{2}{*}{$\begin{array}{c}\text { SPECIME } \\
\mathbf{N}\end{array}$} & \multicolumn{3}{|c|}{$\begin{array}{c}\text { COMPRESSIVE } \\
\text { STRENGTH } \\
\left(\mathrm{N} / \mathrm{mm}^{2}\right)\end{array}$} \\
\hline & & & $\begin{array}{c}7 \\
\text { day } \\
\text { s }\end{array}$ & $\begin{array}{c}14 \\
\text { day } \\
\text { s }\end{array}$ & $\begin{array}{c}28 \\
\text { day } \\
\text { s }\end{array}$ \\
\hline \multirow[t]{4}{*}{1} & \multirow[t]{4}{*}{800} & 1 & 0.67 & 1.67 & 3.1 \\
\hline & & 2 & 0.7 & 1.7 & 3.2 \\
\hline & & 3 & 0.7 & 1.7 & 3.2 \\
\hline & & Average & 0.69 & 1.69 & 3.17 \\
\hline
\end{tabular}

\section{CONCLUSION}

The investigation results are concluded the following conclusions:

$>$ The compressive strength of foam concrete is directly proportional to density of foam concrete.

$>$ The higher density gives higher strength but it is not true all the time.

$>$ The water content plays important role in foam concrete, the ideal water- cement ratio is $0.5-0.8$

$>$ The dry density also ranges from 2.72 to 2.78

$>$ Maximum dry density arrives in mix 3

$>$ The maximum plastic density arrives in mix 1 where maximum workability achieved.

$>$ Replacement of sand with fly ash and cement with Alccofine will result in increase of strength of concrete. Replacement of fly ash and Alccofine should be limited to certain percentages, such as fly ash $(70 \%-100 \%)$

$>$ Alccofine $(0 \%-30 \%)$. If we cross the limits then the strength gradually decreases and workability. 


\section{References}

1. Dr.A.S. Kanagalakshmi et al. An investigation on foam concrete with quarry dust replacement for filler in mix design) International journal of emerging technology in Computer Science and Electronics, volume-13, issue-1(March 2015)

2. Ravi Shankar $\mathrm{S}$ et al. Experiment on Foam Concrete with Quarry dust as Partial Replacement for Filler) International journal of Engineering Research and Technology, volume-4, issue-03 (2015)

3. K Muthusamy et al. Properties of concrete containing foamed concrete block waste as fine aggregate replacement) IOP conf. Series: Materials Science and Engineering 217 (2017)

4. Mr.S. Yuvaraj et al. Experimental Research on Foam Concrete with Partial Replacement of Sand by M-sand) International Journal of Advanced Technology in Engineering and Science, volume-3, issue-1(August 2015)

5. Anchula Nagarjuna, T. Suresh Kumar, B.Yogeswara Reddy, M.Udaykiran, International Journal of Innovative Technology and Exploring Engineering, Vol. 8 no. 11, pp: 640-645, (2019)

6. Aswathy.M Experimental study on light weight foamed concrete) International journal for civil Engineering and Technology, volume-8, issue-8 (2017)

7. T.srinivas and G.Sukesh Reddy Mechanical Properties of Geopolymer Concrete Made With Partial Replacement of Coarse Aggregate by Recycled Aggregate International Journal of Engineering and Advanced Technology, Volume-9 Issue-1(2019)

8. Satyanarayana, G.V.V. Saikiran, C.H. Effect on mechanical properties of M35 grade concrete by partial replacement of fine aggregate with copper slag International Journal of Innovative Technology and Exploring Engineering, Volume 8 Issue 12 (2019)

9. Reddy, V.M., Manikanta, S. Mechanical properties of fibre reinforced self compacting concrete using rice husk ash International Journal of Recent Technology and Engineering, Volume8, Issue 3, (2019), 